se modes of relating, classically between different generations in a teacherstudent relation. Last but not least, technai involve an ethos, because of their relationality but also, in a connected sense, because they are concerned with their consequences, with what they produce in the world of experience.

These characteristics make techniques a promising candidate to develop conceptual tools that cut through accustomed divisions inherited from modern frameworks: they refer to the arts, crafts, and sciences alike and point to the element of artistry and skill inherent in all of them - the necessity for training oneself in particular modes of doing, thinking, perceiving, and sensing. What seems most important to me however, not just regarding FORMATIONS, is that they do not imply a distinction between the modern and the nonmodern. Centering our attention on techniques, rather than on disciplines or specific content, thus helped us to sidestep the binary between modern and nonmodern practices, which we had to accommodate in our heterogeneous group of participants coming from the natural sciences, the humanities, and the arts as well as physical and spiritual practices. Working on creating techniques of transdisciplinary encounter in experimental and often playful ways was our way to respond to our quest for practical responses to the insufficiencies and the persistence of modern habits of thought. And maybe it is even from such kinds of reflection on transversal encounters in practice that a relational epistemology - looking at the diffraction of practices and their interference patterns - may emerge.

As befits the subject of this paper, many minds and bodies contributed to it. I would like to especially thank Alex Martinis Roe, all members of FORMATIONS of its first phase Roman Brinzanik, Descha Daemgen, Deborah Haaksman, Rebekka Ladewig, Wietske Maas, Julian Schubert, Hendrik Weber, and Thilo Wiertz - as well as the editors of this book, especially Maximilian Haas and Annika Haas.

\title{
Sibylle Peters \\ How to Relate Differently: Scenes of Shared Research \\ from the Programs \\ "Performing Citizenship" and "Assemblies \& Participation"
}

How do we relate - when we gather, when we assemble, when we speak for each other, when we claim our rights and fight for them? How do we relate through the performance - or the performative dimension - of assembling, of decision-making, of representing and protesting? How do people start to relate differently in these practices? And are the respective shifts and changes connected to that performative dimension? These questions have 
been at the center of the research programs "Assemblies \& Participation" and "Performing Citizenship" conducted since 2012 by a hybrid combination of institutions in Hamburg: a theater for children and a center for choreography as well as university departments for design and for urban cultures. ${ }^{1}$ Together they hosted about twenty research projects, predominantly in the form of practice-based PhDs, exploring how citizenship is performed today, how it is changing, and how performance art practices might be involved in that.

In the following, I'd like to zoom in on two scenarios of shared research from these programs to show - or, more precisely, to let readers see through involvement - how participatory art-based research allows us to relate differently: by presupposing and enacting the right to research for everybody involved, and by using art - as a frame, discourse, and toolbox - to navigate theory and practice in ways that bring heterogeneous researchers together in pursuing experimental goals.

Kerstin Evert, Gesa Ziemer, and I started these research programs with the intention to prove that artistic practices have the potential to make research more inclusive and accessible, that they can help to organize and support everybody's research. Current debates about artistic research have often missed this perspective, as they have focused on methodologies in between art and science or academia. In contrast, the focus of these programs has been on the relations between research and society and the question of how art practices might help to change them. Just like in the conceptual framework of the program "Das Wissen der Künste" ("Knowledge in the Arts"), the arts are conceived here as relational, embodied, situated, and temporal practices, which bring heterogeneous agencies, materials, and sources in new relations to each other - in other words: as practices that have an expertise of how to relate differently. We reckoned that the question whether art-based research will be successful or not does not depend on how well it fits in with academic standards but on the question of whether it can help to make research meaningful for the many. Therefore, all the projects of the program had experimental parts in which members of the program shared the process with people who were neither from the arts nor from academia but had firsthand knowledge about the issues in question. Thus, the projects took shape in heterogeneous groups of citizen researchers.

With this approach, we followed a demand Arjun Appadurai made in 2006 from the perspective of the Global South. He made a plea for research to be recognized "as a more universal and elementary ability ... a specialised name for a generalised capacity to make disciplined inquiries into those things we need to know, but do not know yet." Appadurai further argued that "knowledge is both more valuable and more ephemeral due to globalisation, and

1 The institutions involved were FUNDUS THEATER/Theatre of Research, K3-Zentrum für Choreographie, University of Applied Sciences (HAW), and the Hafencity University of Hamburg. 
that it is vital for the exercise of informed citizenship."2 Against this background, the programs were an experiment in which we were all personally involved: What if citizenship can be changed towards including the right to research? How to relate differently in the way we perform citizenship today? These were not just research questions but also questions of methods and proceedings within that research. They were political as well as artistic questions, too: what role do the arts play in the current refiguration and crises of citizenship?

One major problem representative democracies face nowadays is that they are mostly incompatible with alternative forms of civil self-organization, especially those developed during the last ten years, since the financial crisis, by the square squatters and the Arab Spring. Since then we see movements without leaders, where the many organize themselves in horizontal ways, using digital tools that make classical political representation look like yesterday's industrialism. ${ }^{3}$ Another, even more pressing problem is that national democracies seem utterly unable to contribute to the development of transnational, global, or planetary forms of citizenship. The scenarios of shared research discussed in the following are chosen because of their close link to these two challenges of citizenship today. They are both situated in politically highly charged places in Hamburg: the Gängeviertel, a contested housing complex, and the Afrika-Terminal, an abandoned part of the Hamburg port with a long colonial history. Both research scenarios also refer to other projects within and outside the research programs, which will be briefly described to show how the projects were relating to each another.

\section{Citizen Researchers}

A first zoom brings us into a gallery space in Hamburg's Gängeviertel, a complex of historical working-class buildings in the center of the city, which have been rescued by artists who squatted them a few years ago, succeeding miraculously: the city of Hamburg bought the complex back from the investor who owned it, and the artists from Gängeviertel formed an association to take charge of the housing complex. Both sides, the city administration and the former squatters, got together afterwards to plan how to renovate and use the buildings in the future. However, this didn't go well. The gap between administrative institutions of representative democracy and the DIY-spirit of the artist collective could not have been more visible as when the artists finally left the table of negotiations in protest against the economic standards the city tried to inflict on them. The process of renovation was stopped. An activist named Michael Ziehl read out the statement in which the squatters declared that negotiations had failed.

2 Appadurai, Arjun, "The Right to Research," in Globalisation, Societies and Education, vol. 4, no. 2, 2006, pp. 167-177, here p. 167.

3 geheimagentur, Schäfer, Martin, and Tsianos, Vassilis (eds.), The Art of Being Many: Towards a New Theory and Practice of Gathering, Bielefeld 2016. 


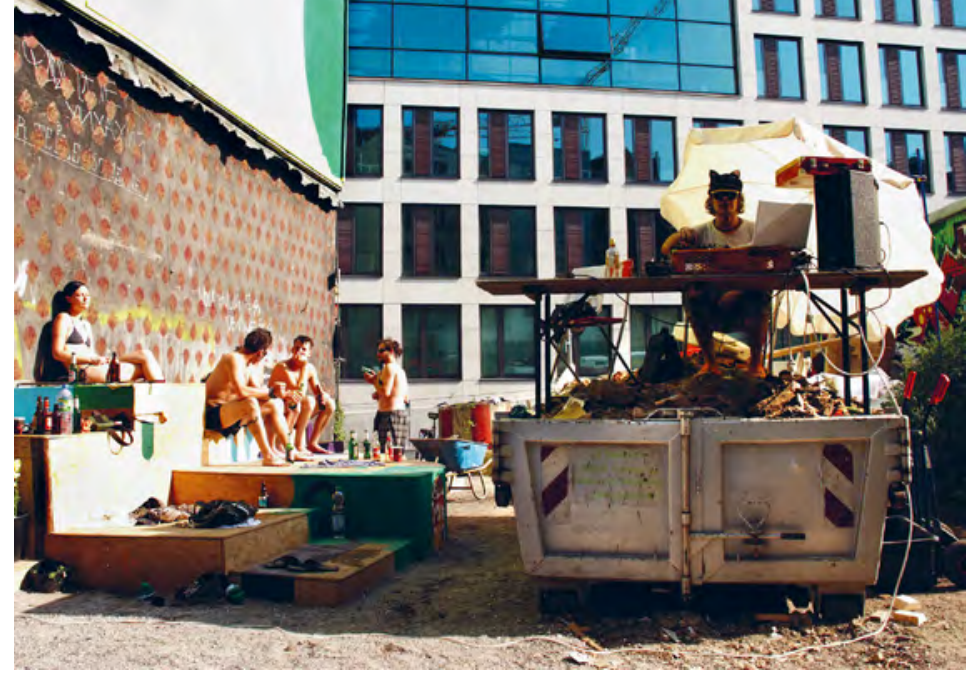

Hamburg’s Gängeviertel

Today, at this gallery space in the Gängeviertel, Ziehl is back on the scene, taking on a new role: he is now a researcher, a PhD student of the program “Assemblies \& Participation.” His starting point is the question: can research step in when all other options of coming together and moving forward seem to be exhausted? Ziehl's project is to conceive of and conduct a mediation process, including artistic practices, in order to bring the two sides of the conflict, squatters and administration, back into dialogue. And he did in fact manage to gather everybody in one room and get them to talk to each other again. How did he do it? All members of the research program would like to know. But the representatives of the local municipal administration demand full secrecy - as they don't feel comfortable as objects of research - and full control over the public outcomes of the mediation process, which is why, now, at the end of a long day of hands-on mediation, Ziehl is not allowed to tell us what actually happened.

Instead he is hosting an evening of lectures and general discussion: classical acts of social science serve as stand-ins, since the experiences and insights of the actual mediation process can't be shared at this point. That's how we all have come to be sitting in the gallery space listening to social scientists lecture about typical problems between local municipal administrations and citizen initiatives. All participants from the conflict are present in the room: administrators, squatters, artists, citizens, researchers - all listening. Usually, social scientists operate within the framework of modern theatrical conventions: they present themselves as uninvolved observers who observe the conflicts between citizen initiatives and administration without bias. In the safety of their theater seat, they seem to lean back and analyze the performances of participants of these conflicts. Tonight though, in this gallery space, the social scientists are performing on the scene, and the participants of the conflict in question are leaning back in their seats watching the performance of scientific presentation. The elephant in the room - the actual, but secret, mediation process - renders the rituals of scientific presentation into as many opportunities for comic relief. The words used by the scientists to 
describe what people are experiencing seem strangely inadequate. The audience is giggling. Against this background Ziehl - the host of the evening, exhausted from the nonpublic part of the day - becomes recognizable as a very different kind of researcher. While the social scientists claim and create a gap between those who act and those who know, a gap that, tonight and in front of this audience, appears as a self-preserving and self-proliferating strategy of professional researchers, Ziehl asks a different set of questions that are at the same time practical and epistemological: How can research become a strategy of political practice? How can participants in a conflict that they would like to solve claim research as a chance to change their perspectives and overcome this standstill?

Ziehl does this first of all by acknowledging the research the participants of the conflict are already carrying out as well as the fact that nobody knows the answer and nobody knows better. After all, the participants of this conflict are trying to solve an unsolvable problem: the question of how to relate differently. Ultimately, the conflict between those who represent "the people" in the framework of the municipal administration and representative democracy, on the one hand, and those who claim to speak for themselves as citizens, taking local problems in their own hands, on the other, is a crack in the concept of citizenship itself. Often people refer to this crack by using the vocabulary of representative vs. direct democracy, which is self-evident but not very helpful. In order to shift this important discussion towards more differentiated ways of how to relate, and not simply placing representation on one side and immediacy on the other side of a dualism, the program "Performing Citizenship" suggests that we speak about how we perform citizenship instead: wherever citizens organize as initiatives or gather around a common cause, representation is always already at stake.

As a part of The Right to the City movement, the activists of Gängeviertel consciously work with this approach and claim to represent interests that are much broader than just their very own. Members of the administration criticized this claim to speak for others as elitist, doubting that the artistsactivists were actually closer to the people than mainstream politicians. Being not only members of the administration, but citizens themselves, they didn't want to be represented in this way. And according to members of Gängeviertel, it is precisely here that dialogue starts again: in a liminal space in which nobody is just executing an official role, and nobody is just themselves, but roles and positions and representation are performed in complex yet changeable ways. Representation is as inescapable as its cracks are. And these often go right through individual subject positions, especially in cases of conflict, which are a given when it comes to the res publica, the question of the public. Researchers who claim to be representatives of knowledge may well confuse things further when representation itself is in question. Instead, in order to support each other in civil conflicts like this it might help to acknowledge that we all are citizen researchers and citizen performers - despite everything. 


\section{Shared Knowledge Production}

Research projects within the programs "Assemblies \& Participation" and "Performing Citizenship" often meant proving the possibility of a certain type of artistic intervention in the refiguration of citizenship, simply by trying it out. However, the modes of trying out, the propositionality of enacting alternative yet real scenarios, are anything but simple. To develop a valid situation of trying things out, in most of the projects the artistic practices were much more visible than in this first scenario, in which the actual process remained in the dark. For example, the Entscheidungsspielraum (or space of decision) was a space designed for collective decision making, a room equipped with performative tools to empower and inspire heterogeneous collectives in rethinking and enjoying their performance of decision making (FUNDUS THEATER / Theatre of Research 2013 and ongoing). This research project by Hannah Kowalski started from the observation that participatory processes, as, for example, in urban planning, have incorporated all kinds of creative practices but risk becoming spectacles of participation as long as they leave the real decision-making for later. How about some creativity when it comes to decision-making itself? Kowalski developed and tried out her Entscheidungsspielraum together with a group of elementary school kids, who were enabled by this project to take part in the decision-making process of urban planning for the first time.

Sylvi Kretzschmar's research project on amplification, to give another example, began with a historical analysis of how forms of public manifestation have been informed and changed by specific techniques of amplification and their development. The experimental aim of the project was to develop a new form of amplification that relates people differently and that is informed by the social conflicts around gentrification. Kretzschmar interviewed former tenants of what are known as the Essohäuser, a building complex in Hamburg St. Pauli that fell victim to speculation. From these interviews, she isolated statements, slogans, and expressions of anger and mourning, which were then amplified in public manifestations by what she called the Megaphonchor, an all-female group of activists and artists each equipped with a megaphone, performing choreographies of protest and mourning on the streets (Public Address System, 2013-2016).

A first evaluation and collection of data at the end of the official duration of the programs showed that the goal to involve people from outside of art and academia did work out: the twenty research projects counted no less than 750 participant researchers, people who were intensely involved in collective research, such as the child collaborators in Kowalski's project, the participants of conflict in Michael Ziehl's project, or the tenants and activists in Kretzschmar's Megaphonchor. A further 1500 people took part in collective research at some point of the projects. In addition, more than 160 collaborations between various institutions took place to organize and support collective research, including not only cultural and academic institutions but also small companies, 
churches, or schools. But why is a quantitative perspective relevant here? In the humanities, the doctorate is mostly a lonesome endeavor that ties people to desks, archives, and databases. By contrast, $\mathrm{PhD}$ researchers from our programs were asked to build meaningful associations of heterogeneous research participants: artists, scholars, activists, children, members of the municipal administration, neighbors, etc. How did they relate?

Although all these participants were part of the same collective research process, they had very different agendas: children who are asked to decide on the best possible setup for a playground or activists who ask how to fight gentrification effectively do not have the same research question as $\mathrm{PhD}$ students who are researching performances of decision-making or the development of new forms of amplification. Based on an open concept of research including everyday practices of trial and error, and assuming a right to research for everybody, all these different agendas were considered equally valid. None is in itself more important or more significant than the other. However, this equality does not and should not translate into equal tasks or responsibilities in the research process. In leaning on the resources and the conceptual advice provided by the programs, it is the members, i.e., the $\mathrm{PhD}$ students, who are responsible for coordinating everybody's research, for creating reasonable relations between the different agendas and specific expertises. They are responsible for creating a process in which research and public presentation are related in a way that generates productive outcomes for all participants and their agendas. If this is achieved, participants not only carry out research together; their different kinds of research give each other momentum and context, enable each other, and thus become an experiment of performing citizenship on yet another level - that of shared knowledge production.

An important point of reference for the theoretical reflection of the framing of the different projects within the programs has been Engin Isin's theory of citizenship. This theory focuses on "acts of citzenship" 4 that manage to change the concept of citizenship by performing an act $a s$ if those performing it had the right to do it, as if the respective right existed. These are, in other words, acts which perform - to use Hannah Arendt's language - the right to have rights as such, ${ }^{5}$ in the sense of tryouts of an alternative civic reality. Such claims often go along with acts of instituting. Alternative civic realities ask for alternative semi-institutional bodies. The programs saw many of those coming into being: in addition to the Megaphonchor, there was the School of Girls (Maike Gunsilius), the Institute of Falsification (Thari Jungen), the Institute of Choreologistics (Moritz Frischkorn), The Youngest Court (Elise von Bernstorfi) and many others. Perhaps the programs produced semi-institutional bodies

4 Isin, Engin and Nielsen, Greg, Acts of Citizenship, London 2008. Isin, Engin, "Doing Rights with Things: The Art of Becoming Citizen," in Hildebrandt, Paula, Evert, Kerstin, Peters, Sibylle et al. (eds.), Performing Citizenship: Bodies, Agencies, Limitations, London 2019, pp. 45-56.

5 Arendt, Hannah, "Es gibt nur ein einziges Menschenrecht," in Die Wandlung, vol. 4, autumn 1949, pp. 754-770. 
of this kind in such abundance because they themselves were hybrid bodies in which all members constantly experienced what it means to speak on behalf of different bodies, what it means to switch between them. For example, as founder and temporary speaker of the program I was not, as one might assume, a professor at the Hafencity University, but artistic director of a children's theater. We all constantly had to choose: were we speaking as an activist of The Right to the City movement, on behalf of the university, or in the name of the program or the theater? We performed the body of research with flexibility and in ongoing hybridization.

\section{The African Terminal}

Zooming in on another of those hybrid bodies, the African Terminal, the question of how to relate differently shifts to the second major crisis of citizenship mentioned above: the inability of nation states to develop a form of transnational citizenship that would be more adequate to the actual way in which people and things are related to each other in global economies. The African Terminal came into being as a conjunction of three different research projects carried out within the program. Moritz Frischkorn's Institute for Choreologistics explored how choreographic knowledge and practices could be used to understand and possibly to intervene in the current boom of logistics, the so-called logistical turn. The sound artist Katharina Pelosi worked on a postcolonial sound archive for the city of Hamburg. And together with the geheimagentur art collective, I worked on a project called the Free Port Baakenhöft: we were planning to reopen an unused part of the port as a temporary space for everybody to claim their right to the port. The Free Port Baakenhöft was a complete port with several elements: a jetty for the experiments of rafters, radical seafarers, and offshore artists; a ship-welcoming station that worked as an open mic for citizens to address cruise and container ships; an archive called the Hydrarchiv, in which documentation from more than a hundred artist and activist interventions and projects in Hamburg port was collected; and the African Terminal. There were several reasons why the Free Port Baakenhöft had to be situated right at the Baakenhöft, but the most important one was the history of the place that, until fairly recently, served as the Afrika-Terminal of the Hamburg Port. The Baakenhöft is also the place where the Deutsche Ostafrikalinie was moored and the place where, from 1904, German troops were shipped to Namibia, formerly Deutsch Ostafrika, to commit the first genocide of the twentieth century, the murder of the Herero and Nama.

Together, geheimagentur, two groups of former refugees from Gambia, Nigeria, and Ghana, Moritz Frischkorn, and Katharina Pelosi formed the African Terminal, a cooperative in the making, suggesting and testing how the old, no-longer used Afrika-Terminal could be turned into a hotspot for trade on the part of African migrants, a place for informal, citizen-driven sea trade. Over the course of a month, the members of the African Terminal group, with the help of the public, filled a $40-\mathrm{ft}$ container with goods that had been 
donated but were still in a condition to be used and shipped it to Banjul in Gambia, where the contents were sold to create a small income for the members of the African Terminal, who have no other source of income. Together we - migrants, artists, and researchers - learned hands on about customs, container logistics, and how to become our own sea trade agents. Moreover, through an audio guide made by Katharina Pelosi and several public events, we informed visitors about the history of the place, as well as the relation between migration and informal trade. We invited citizens and noncitizens of Hamburg to use the African Terminal as a tool to rediscover their connectedness through the port and the seas and to do research with us on how alternative citizen-driven oversea supply chains might be created.

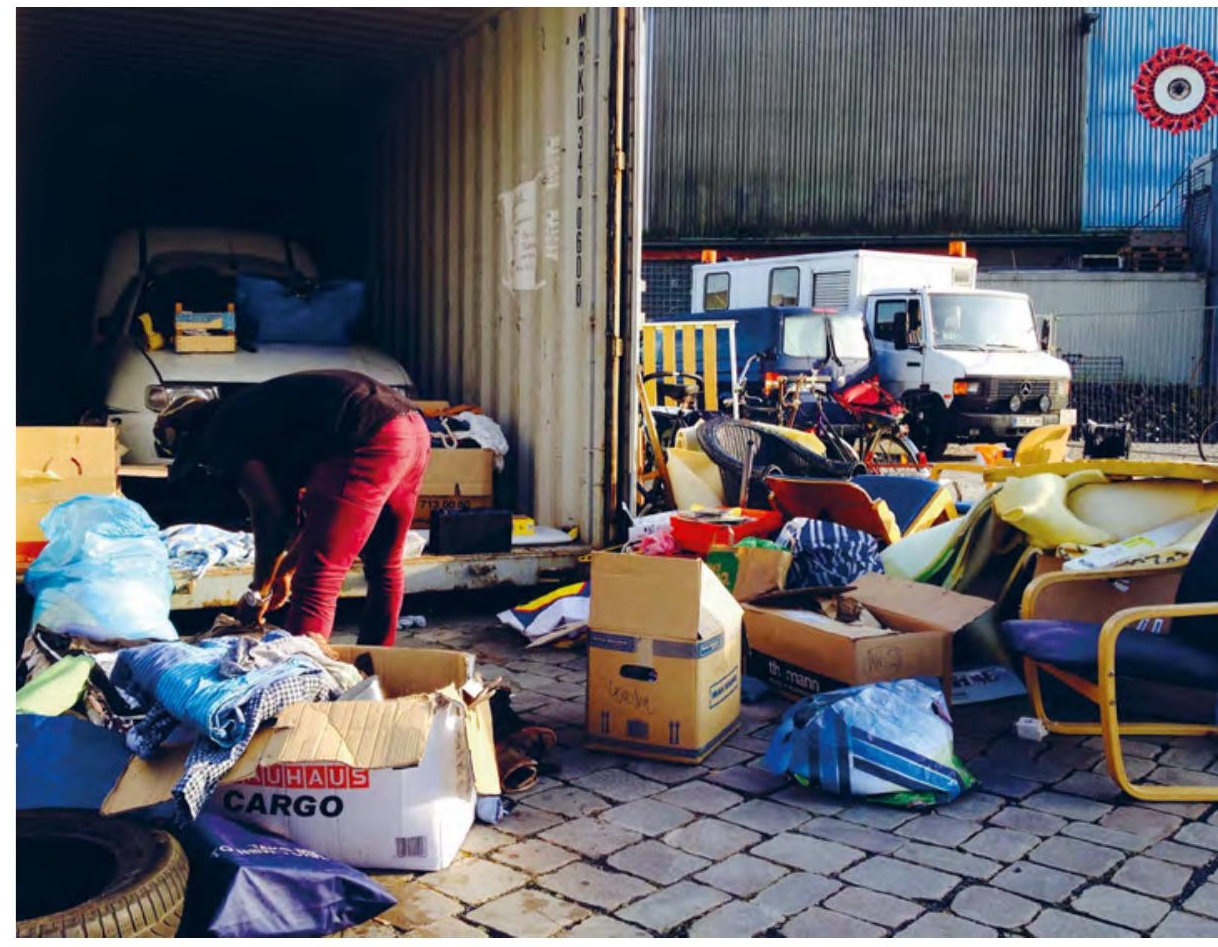

Participants of the African Terminal project shipping goods

One might argue that, as members of a research program "Performing Citizenship" focusing on performance theory and practice in regards to the city, we were pretty far out of our comfort zone and our fields of expertise when we started dealing with the details of oversea trading. This is true. And it's also why, in order to explain how the African Terminal made us relate differently, I have to start a few years earlier - in 2010, when a group of Somali pirates hijacked the cargo ship MS Taipan that was sailing under German flag. Dutch naval forces captured the pirates and brought them to Hamburg for trial. It was the first piracy trial in Hamburg since 1624. Given that there 
is no birthday party without a treasure hunt and that a kid pirate called Captain Sharky was depicted on their toothbrushes, the children who visited the Theatre of Research were curious: "How come the pirates escaped from the movies and why does nobody like them anymore, now that they are real?" The children were thus asking questions that all of us had but no adult dared to ask. We, the team of the Theatre of Research and the art collective geheimagentur, therefore decided to invite the children to dress up in their pirates' costumes, recording their questions for real pirates on video.

Exploring the idea that everyone on this planet is connected to everyone else through no more than seven links, ${ }^{6}$ we asked friends of friends of friends if they knew any Somali pirates. After a remarkable odyssey, we finally found them in Eastleigh, the Somali part of Nairobi, in the club room of a hotel. The pirates were more afraid of us than we were of them. But watching the kids' videos made them relax. The pirates opened up and really tried to give an account of what had happened - so that the kids in Hamburg could understand.

While we brought the answers of the pirates that we had recorded on video back to the children of Hamburg and transformed this improbable dialogue into a stage performance, the Operation Atalanta naval mission slowly managed to reinstate what has lately been called supply chain security, and the shipping industry of Hamburg founded a training center for private antipiracy forces to protect their ships. These forces, trained in a remote industrial zone of the city, were more than discrete; they never took prisoners and no one in Hamburg ever heard of their actions again.

Considering that the shipping industry of Hamburg had made donations to the Theatre of Research in the past, we realized that, by connecting children and pirates in this improbable dialogue, we had enacted a link that had already existed but remained hidden from our sight. We understood that something crucial had happened to the logistics of the port during the last decades. And not just to "our" port. London, New York, Hong Kong - port cities around the world have moved their docks and terminals out into special zones with no connection to the urban space that citizens inhabit. Containerization has brought about the expulsion of labor from the ports. At Hamburg's Euro Terminal, no more than five people are needed to unload the world's biggest containerships in less than a day. Less than twenty people work on these ships and usually none of them is from Hamburg. We suffer from "seablindness," the chief of the British Navy said. ${ }^{7}$ geheimagentur collective and Theatre of Research decided to ask: "What if we - as citizens of Hamburg had a right to the port? What would a performance of this right look like?" Connecting it to Engin Isin's concept of acts of citizenship, this was the research project I brought to the program "Performing Citizenship" on my own

6 First introduced by the Hungarian author Frigyes Karinthy in his story Láncszemek (Chains) in 1929.

7 George, Rose, Ninety Percent of Everything, New York 2013, p. 4. 
behalf. Meanwhile, more and more people from Africa arrived in Hamburg after a dangerous crossing of the Mediterranean Sea. These people were noncitizens for now, but they were not seablind. Instead they were in Hamburg for a reason: they were determined to use the port to send goods to their home countries. I conducted extensive interviews with five of them. During these conversations the impression of talking to refugees faded, though most of them in fact had horrific reasons for fleeing their country. Nevertheless, I realized that I was actually talking to aspiring African businessmen from the lower and middle classes of their countries who were trying to turn things around: they were looking at Europe from the perspective of what they could extract from it, what they might set in motion in order to support West Africa. But at the same time, they were researchers in building alternative supply chains from Europe to Africa.

The supply chain is an important concept in our context of relation: since the 1980s the focus of business education and management has shifted from the company as the main unit of economic consideration to the supply chain. In globally connected markets, it is not companies who are competing against each other but associated supply chains, which consist of several, often very different, companies. Imagine the multitude of regulations, infrastructures, and practices - from custom handling to packaging techniques to money flow that all have to be synchronized to get such a supply chain working. Look at the things that surround us here - clothing, furniture, technical equipment. Make a guess: how much of it has been shipped before? Rose George turned the answer to that question into the title of her book Ninety Percent of Everything. ${ }^{8}$ In critical theory, this has been described as capitalism's logistical turn. In a paper on "Extraction, Logistics and Finance," Sandro Mezzadra and Brett Neilson write: "Stemming from military practices, logistics organizes capital in technical ways that aim to make every step of its 'turnover' productive." Capitalism itself has thus become the movement of movements. UPS, a global player in logistics, describes this as follows: "We love logistics. Each day, our customers count on us to choreograph a ballet of infinite complexity played across skies, oceans and borders. And we do."10 Far out of our comfort zone, we understood that the supply chain is for our time what the assembly line was for Fordism. And it is the figuration of the global. From Anna Tsing's analysis of "supply chain capitalism," we learned that supply chains are by no means new - what is new is only the hype and the promise that is connected to them, a promise that has brought new kinds of entrepreneurs to the table. ${ }^{11}$

8 George 2013, p. 4.

9 Mezzadra, Sandro and Neilson, Brett, "Extraction, Logistics and Finance," in Radical Philosophy, no. 178, 2013, pp. 8-18.

10 United Parcel Service (UPS), ad campaign, October 2010.

11 Tsing, Anna, "Supply Chains and the Human Condition," in Rethinking Marxism: A Journal of Economics, Culture \& Society, vol. 21, no. 2, 2009, pp. 148-176, here p. 149. 
Against this background, the African Terminal can be understood as a practical yet experimental exploration of supply chain capitalism, starting from the dead ends of supply chains, starting from the outside, literally from those places where supply chains never reach. Even from this perspective, we got a glimpse of what Tsing describes as a process, in which

nonwork tropes - particularly tropes of management, consumption, and entrepreneurship - become key features in defining supply chain labor. Here, the new styles attributed to capitalism become entangled with the experiences of workers. Chain drivers control some but not all of this subjectification. I argue that workers learn to perform within these tropes. ${ }^{12}$

Allow us to take a look at such subjectifications in the process of becoming and zoom in on another situation of shared research that took place in autumn 2018 at the Museum für Kunst und Gewerbe in Hamburg, more precisely, in the exhibition Mobile Welten/Mobile Worlds, curated by Roger Bürgel. Invited to participate, the African Terminal has just moved its storage space into the middle of the exhibition and opened it to the public. Around forty people have gathered here: the traders and researchers of the African Terminal alongside thirty visitors. Together, we are looking at the model of a supply chain, laid out on the floor; we are also looking at maps of global supply chains and migration, and we are having a discussion. It is a simple classic model of a supply chain that describes the movement of things from the first supplier to the customer:

\section{Product $\rightarrow$}

Supplier - Production - Distribution - Trade / Sales - Customer Information $\leftarrow$

In this model, the supply chain is a line that potentially crosses and binds together a multitude of differences: differences of wealth, of laws and regulations, of infrastructures, of cultures. Looking at the model, members of the African Terminal notice that it focuses on the movement of things rather than on the movement of people. The supplier, the worker, and the customer are local entities in a system that is designed to transform and move along things, turning them into goods. Yet if we overlap a map of global migration on top of a map of global supply chains, with their respective hubs and connections, we see that they match: people are migrating away from those places left out of the global supply chain networks. The traders of the African Terminal agree that much depends on how this matching of the maps is interpreted. Traditionally, we would argue that in places of crisis, the economy is down, which makes people migrate. However, there are lots of people still living in those places who are left out of the network of supply chains. In fact, 
it doesn't look as if the movement of things is following the movement of people. Instead the movement of people seems to be following the movement of things, as people try to reach the hubs of the supply chain network.

This is definitely true for the traders involved in the African Terminal. Notwithstanding other reasons for fleeing their country, they came to Hamburg specifically because it is a hub of supply chains and thus a chance to become entangled in the movement of things. However, the global systems of supply chain management do not take migration into account. And the global systems monitoring migration are not interested in the movement of things. Though entangled, the two are kept apart - systematically. So how might we relate the migration of people and the movement of things differently? Perhaps with the help of art and of research?

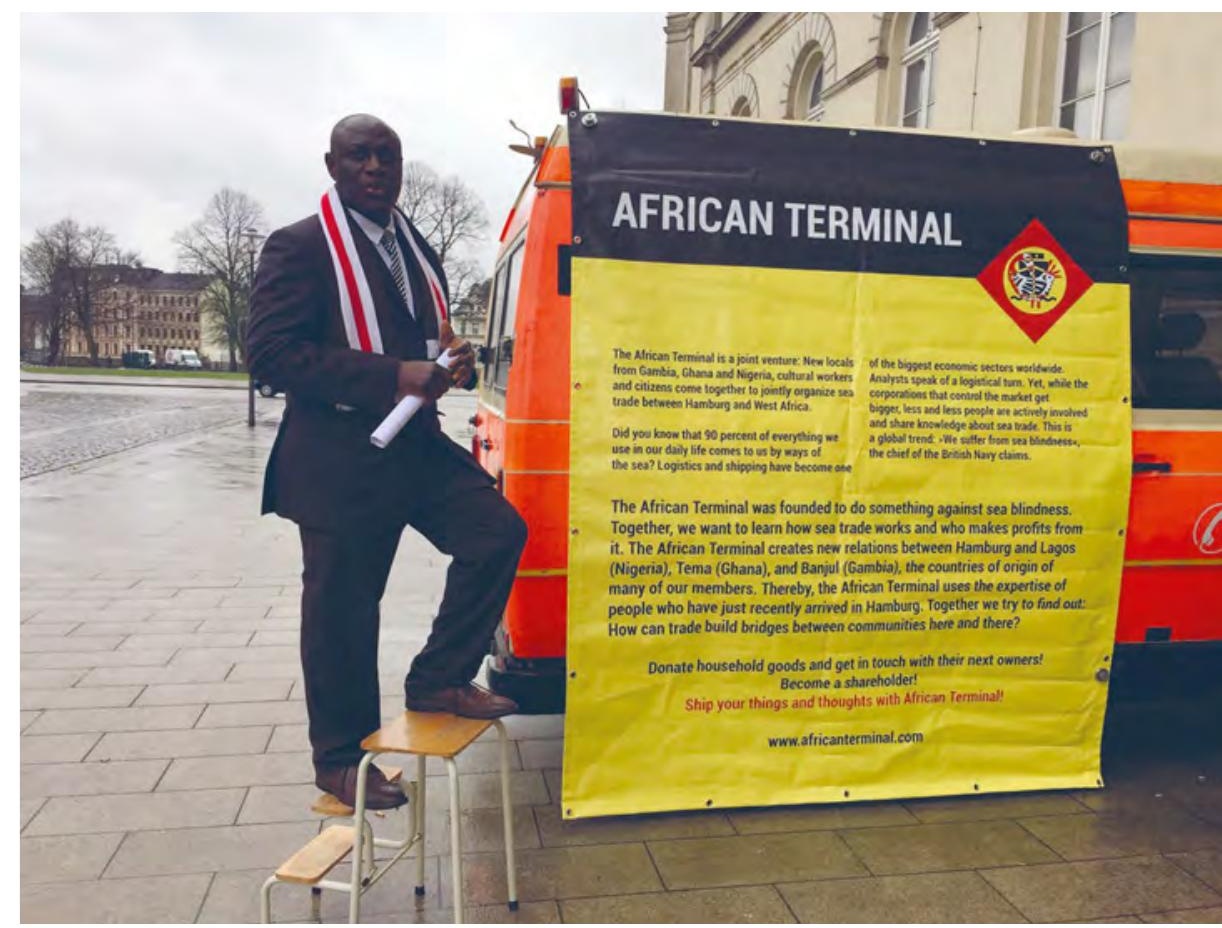

African Terminal at the Museum für Kunst und Gewerbe, Hamburg

Keller Easterling, one of the thinkers of the logistical and infrastructural turn, identifies one possible direction in which to search for an answer. She argues that "global infrastructure space has perfectly streamlined the movements of billions of products and tens of millions of tourists and cheap laborers, but at a time when over 65 million people in the world are displaced." 13 Consequently, Easterling chooses a practical, yet experimental approach and

13 Easterling, Keller, "MANY," in Dimensions of Citizenship, http://dimensionsofcitizenship.org (last access: August 11, 2019). 
suggests putting some of the principles and tools of global logistics to the use of migrants. In the database MANY, which she presented at the Architecture Biennale in Venice in 2018, the African Terminal featured prominently as one of her examples. The idea of starting to build supply chains based on migrational expertise seems to be promising. Imagine that migration would no longer be seen as a journey from beginning to end, as leaving one country behind to ideally become citizen of another, but as an endless entanglement of people and things in motion. Imagine that migrants would finally be acknowledged as experts in this regard. Imagine the multitude of alternative supply chains that people with migrational experience would be able to build. Imagine that they would not be constantly stopped but supported in this endeavor.

Imagine that we were able to relate differently. That we might act as if we were able to relate differently.

It might seem like a wide stretch from performing citizenship within the city to the negotiations and fights in rebuilding and reclaiming citizenship in the interconnectedness of transcontinental migration and sea trade. However, I would like to argue that in order to perform everybody's right to research in a city like Hamburg, and in most big cities today, this is exactly the tension we have to endure - in practice, theory, and research. Even if, for now, the results of this research will not foster global changes of structures but only microchanges, experiencing and understanding these changes has an effect on the collective imagination of what's possible and worth fighting for - as the citizen performers and citizen researchers we are today.

\section{Tom Holert Verkomplizierung der Möglichkeiten: Gegenwartskunst, Epistemologie, Wissenspolitik}

Wie lässt sich ein Meta-Diskurs über situierte Wissen und nichtwestliche Epistemologien im Kontext von Kunst und Kunsttheorie situieren? Vom Standpunkt der Standpunktsensibilität aus zu reflektieren, scheint im Licht einer solchen Frage gleichermaßen unausweichlich wie überaus widersprüchlich zu sein. Die Probleme, die sich in meinem Fall damit verbinden können, ja unweigerlich ergeben müssen, sind nicht über einen schlichten Sprechakt zu lösen, und eine ,Lösung ist auch nicht anzustreben, nicht nur weil sie aussichtslos erscheint. Im Unterschied, sagen wir, zu einer Forscherin mit einem Maori- oder Inuit-Hintergrund kann ich als Person, die sich, soweit dies die Dekonstruktionen des Autorenbegriffs zulassen, auch als Autor dieses Textes 